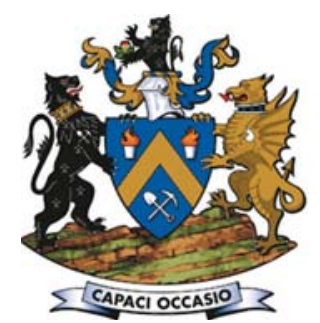

\title{
Relationship between ore mineralogy and copper recovery across different processing circuits at Kansanshi mine
}

\author{
by L. Little, Q. Mclennan, A. Prinsloo, K. Muchima, \\ B. Kaputula, and C. Siame
}

\section{Synopsis}

The variability of copper mineralization at Kansanshi mine significantly affects the efficiencies of the processes used to recover copper. Quantifying this variability is therefore essential for monitoring and optimizing the performance of the concentrator, which comprises three different flotation circuits (sulphide, mixed, and oxide) and an atmospheric leach circuit. Onsite automated scanning electron microscopy with energy-dispersive X-ray spectrometry (Auto-SEM-EDS) is used to analyse routine weekly composite samples for each circuit, providing detailed analyses of bulk mineralogy, copper deportment to different minerals, mineral liberation, and associations. Weekly mineralogical trends are used to assess changes in process performance, and characterization of the copper losses has inspired a number of projects to target the specific particle types responsible for the main losses. In this paper we describe the relationship between mineralogy and plant performance at Kansanshi, and discuss some of the advantages and challenges of on-site process mineralogy.

Keywords

process mineralogy, automated SEM, copper deportment, flotation recovery.

\section{Introduction}

Kansanshi is a copper and gold mine located in the Northwestern Province of Zambia, with an annual production in the region of $250000 \mathrm{t}$ of copper and 160000 ounces of gold. Ore mined from the epigenetic vein-hosted deposit is classified into three ore types based on the extent of oxidation and supergene enrichment. Sulphide, oxide, and mixed ore are fed to separate mineral processing circuits tailored for recovery of the dominant copper minerals in each. After comminution to a target grind size of $80 \%$ passing $150 \mu \mathrm{m}$, each ore type is subjected to flotation to recover the copper sulphide minerals (chalcopyrite, bornite, chalcocite, covellite). The oxide float tails and a large proportion of the mixed float tails are then treated by atmospheric leaching to extract copper from the remaining copper-hosting minerals, which include cuprite, malachite, chrysocolla, and delafossite. Some native copper is recovered by flotation and some of it is recovered by leaching. A small portion of the combined concentrate from all circuits is subjected to high-pressure leaching and the rest is sent to the smelter. Sulphuric acid produced during smelting is used for the atmospheric leach.
With assistance from Dr Will Goodall and colleagues from MinAssist and iMinSolutions, Kansanshi set up an on-site mineralogical section within its processing department in 2015 to provide applied mineralogy services for continuous plant performance improvement. Most features of the set-up that Goodall outlined in 2015 have been maintained to date, with the Zeiss MinSCAN being used for automated mineralogical analysis of weekly composite samples of the key streams for each circuit. In this work, sulphide, mixed, and oxide flotation are considered as three separate circuits, and the atmospheric leach that processes oxide and mixed flotation tails is considered as a fourth circuit. Detailed weekly mineralogy reports for each circuit have helped to explain variation in performance, and have underpinned a number of successful recovery and grade improvement projects. Kalichini et al., (2017) described some of the key successes of the Kansanshi mineralogy programme, focusing on the value delivered by the programme in the sulphide circuit.

Work involving Kansanshi ore mineralogy that has been reported to date has typically focused on mineralogy or processing associated with a particular circuit at Kansanshi (Corin et al., 2017; Kalichini et al., 2017; Jacobs, 2016; Pacquot and Ngulube, 2015; Kalichini, 2015; Pérez-Barnuevo, Pirard, and Castroviejo, 2013). The objective of this paper is to provide a broader perspective, analysing variation in mineralogy across the four circuits and relating this to the operating strategies and performance of each.

* First Quantum Minerals Limited, Kansanshi Mine, Solwezi, Zambia.

(C) The Southern African Institute of Mining and Metallurgy, 2018. ISSN 2225-6253. This paper was first presented at the Copper Cobalt Africa, incorporating the 9th Southern African Base Metals Conference, 9-12 July 2018, Avani Victoria Falls Resort, Livingstone, Zambia. 


\section{Relationship between ore mineralogy and copper recovery across different processing circuits}

\section{Methodology}

The data presented in this paper is from routine weekly mineralogical analysis performed on-site using the Zeiss MinSCAN (Hill, 2014). Automated sample cutters on the cyclone overflows, final tails, and final concentrate streams are used to collect two-hourly samples for chemical analysis. From these samples, daily composites are prepared, which are in turn combined to form weekly composites. The plant sampling equipment and sample preparation procedures are continually being improved with the aim of ensuring full representativeness. This is a work in progress.

After being wet-screened into four fractions, the weekly composite samples (four fractions from three streams in each of the four circuits), are further split using a micro-riffler, mixed with graphite, and mounted in resin. After setting, these blocks are polished and carbon-coated for scanning electron microscopy (SEM) analysis with the MinSCAN. The blocks are analysed using a random grid pattern of fields that are mapped with a 2-14 $\mu \mathrm{m}$ energy-dispersive spectroscopy (EDS) point spacing, depending on the size fraction. Mineral classification, performed using the Mineralogic software, is based on a mineral list that was developed by iMin Solutions. Optical microscopy is used intermittently for corroboration of SEM mineral identification (Figure 1), and this has helped to identify and resolve occasional issues with SEM mineral classification.
Calculations for copper distribution by-mineral-by-size incorporate total copper assays from the Kansanshi chemical laboratory for weighting of the copper deportment to each size fraction. This reduces the errors associated with particle segregation during block preparation. In November 2017, the analysis method for tails samples was changed from X-ray mapping to a bright-phase search to increase the number of copper mineral particles analysed and thus reduce the uncertainty associated with losses of sulphide minerals, native copper, malachite, and cuprite.

Data from the period December 2017 to May 2018 (22 weeks) was selected for description of the bulk mineralogy, copper deportment, copper mineral recovery, and mineral associations across the four circuits. This was due to slight modifications in the mineral list clustering and improvements in the analysis set-up that were implemented in November 2017. However, data for 2016 and 2017 describes similar mineral behaviour across the four circuits as the selected period data.

\section{Bulk mineralogy}

Figure 2 shows the bulk mineralogy of the ore fed to the three flotation circuits, as well as that of the flotation concentrates obtained. The major non-sulphide gangue minerals are quartz, feldspar (albite), mica (biotite,

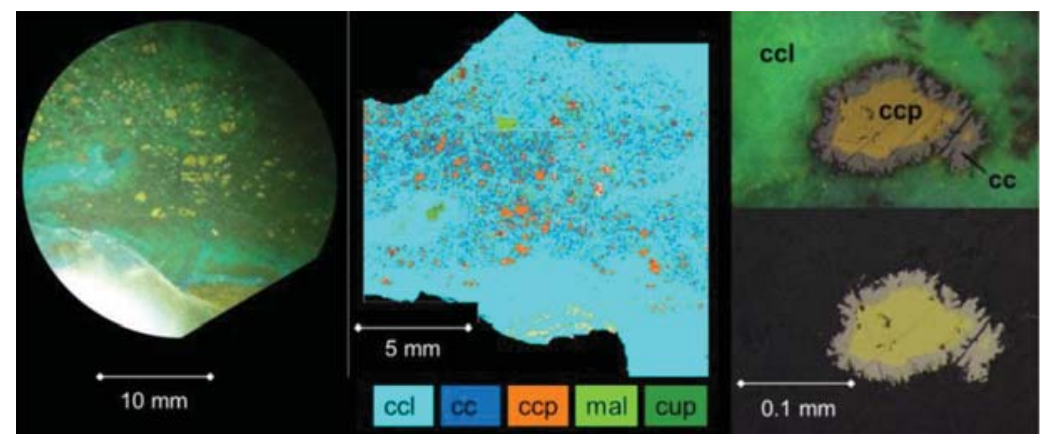

Figure 1-Photomicrographs and a MinSCAN false-colour map of a hand sample (rock) taken from the oxide SAG mill discharge grate. The major component of the rock is chrysocolla (ccl), but it also hosts disseminated chalcopyrite (ccp) grains that have been partially replaced by chalcocite (cc). Finer sulphide grains have undergone complete replacement to secondary copper sulphides, whereas coarser grains retain the chalcopyrite core

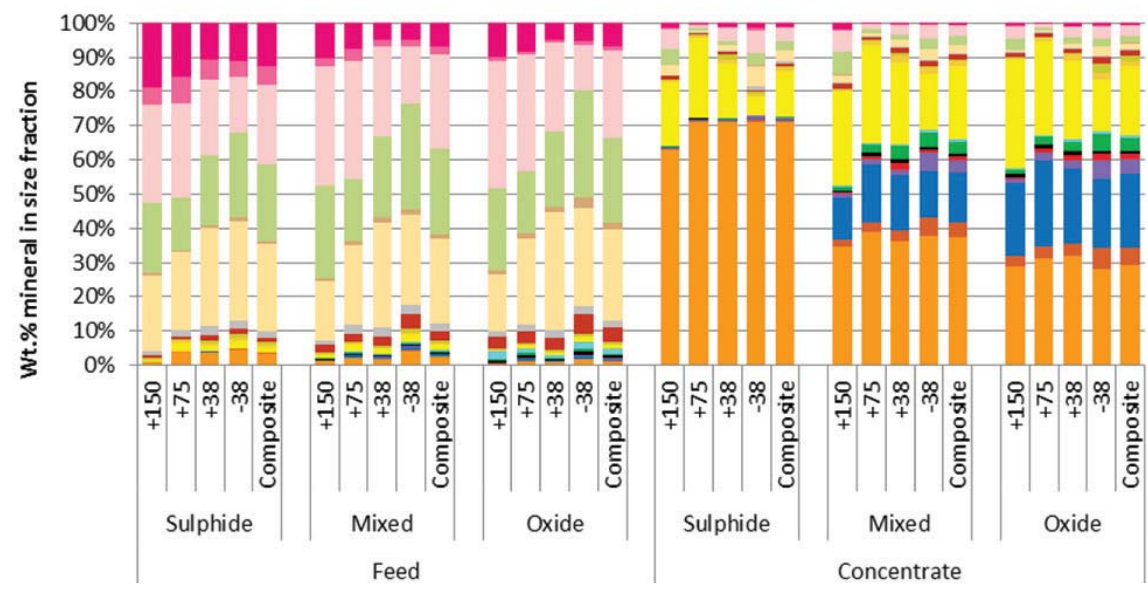

\begin{tabular}{|c|}
\hline 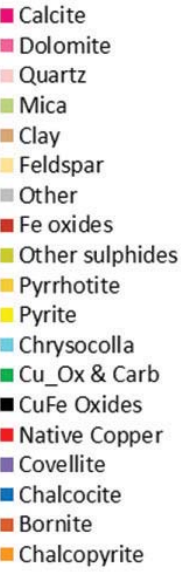 \\
\hline
\end{tabular}

Figure 2-Bulk mineralogy by size for feed and concentrate samples from the three circuits (average over 22 weeks) 


\section{Relationship between ore mineralogy and copper recovery across different processing circuits}

muscovite), and calcite, which together comprise over 80 mass\% of the ore fed to the three circuits. Dolomite, clay (kaolinite), iron oxides (magnetite, haematite, and goethite), and others (rutile, ilmenite, and zircon) comprise another 1020 mass\%. Note that graphite is not shown in Figure 2 as it is not directly quantifiable by EDS, but minor quantities are expected to be present, and at times 'carbonaceous material' does cause problems in the flotation circuits. Additionally, the mica cluster currently includes amphibole and chlorite minerals, which are present in minor amounts. Pyrite, pyrrhotite, and other sulphides (mostly galena) are all minor components of the feeds, with pyrite having the biggest impact on concentrate quality, accounting for $10-20 \%$ of the final concentrate mass.

The bulk mineralogy by size for each circuit shows clear variation in the breakage rates and grain sizes between the major gangue minerals, with quartz and calcite preferentially deporting to the coarse fractions. A substantial proportion of the copper and gold mineralization at Kansanshi is hosted within the network of quartz and calcite veins that crisscross the deposit. The chalcopyrite mineralization within these veins is mostly coarse, so it is easily liberated and preferentially recirculated within the grinding circuits, and therefore it does not follow the same distribution by size as the quartz and calcite. Across the three flotation circuits, the proportions of the acid-consuming gangue minerals (calcite and dolomite) decrease from sulphide to mixed to oxide ore. The relative abundance of these minerals and variation thereof is of key interest for the leach circuit and has at times been used as a means of controlling the acid balance between the smelter and the leach circuit.

The variation in extent of oxidation and weathering across the three flotation circuits is apparent in the ratio of sulphide to oxide minerals in the feeds, with increasing proportions of iron oxides, secondary copper sulphide minerals such as bornite, chalcocite, and covellite, and chrysocolla. The main differences between the concentrates across the three circuits is apparent in the copper sulphide minerals, where supergene enrichment has led to replacement of chalcopyrite with secondary copper sulphides in the mixed and oxide ores (Figure 1). Djurleite and digenite have also been identified (Jacobs, 2016), but these have been clustered with chalcocite. The similarity in bulk mineralogy of the mixed and oxide concentrates does not fully reflect the differences in copper mineralogy between these two ores because the flotation recovery of chrysocolla is negligible. The difference in chrysocolla content is more clearly demonstrated in the following sections.

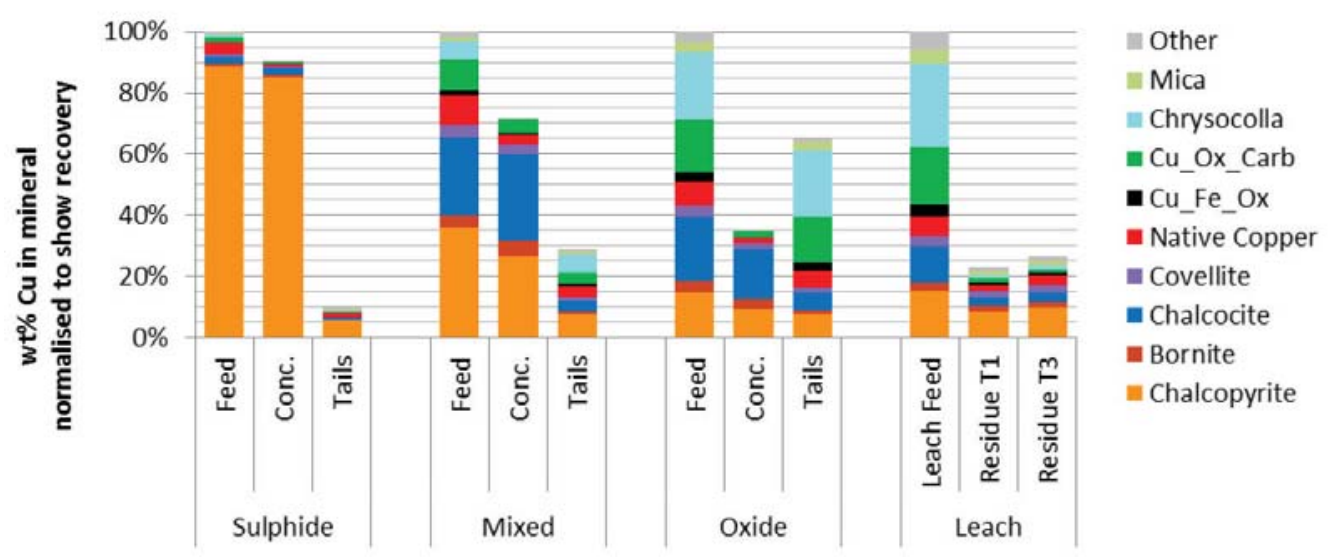

Figure 3-Normalized copper distribution by mineral for the key streams of each circuit, weighted by total copper in each stream relative to the total copper in the feed to the circuit. Residues T1 and T3 describe the final countercurrent decantation thickener underflow streams of the two leach trains used in the current circuit configuration

\begin{tabular}{|c|c|c|c|c|c|}
\hline \multicolumn{6}{|c|}{ Copper mineral recoveries across the three flotation circuits and two leach trains } \\
\hline & \multicolumn{3}{|c|}{ Flotation recovery (\%) } & \multicolumn{2}{|c|}{ Leach efficiency (\%) } \\
\hline & Sulphide & Mixed & Oxide & Train 1 & Train 3 \\
\hline Chalcopyrite & 94 & 78 & 57 & 37 & 34 \\
\hline Bornite & 84 & 86 & 70 & 43 & 40 \\
\hline Chalcocite & 69 & 89 & 75 & 69 & 65 \\
\hline Covellite & 71 & 76 & 62 & 33 & 24 \\
\hline Native copper & 40 & 63 & 37 & 67 & 63 \\
\hline Copper oxides and carbonates & 43 & 55 & 14 & 93 & 94 \\
\hline Delafossite and $\mathrm{Cu}-\mathrm{Fe}$ oxides & 50 & 32 & 10 & 75 & 76 \\
\hline Chrysocolla & 7 & 6 & 1 & 94 & 94 \\
\hline
\end{tabular}


Relationship between ore mineralogy and copper recovery across different processing circuits
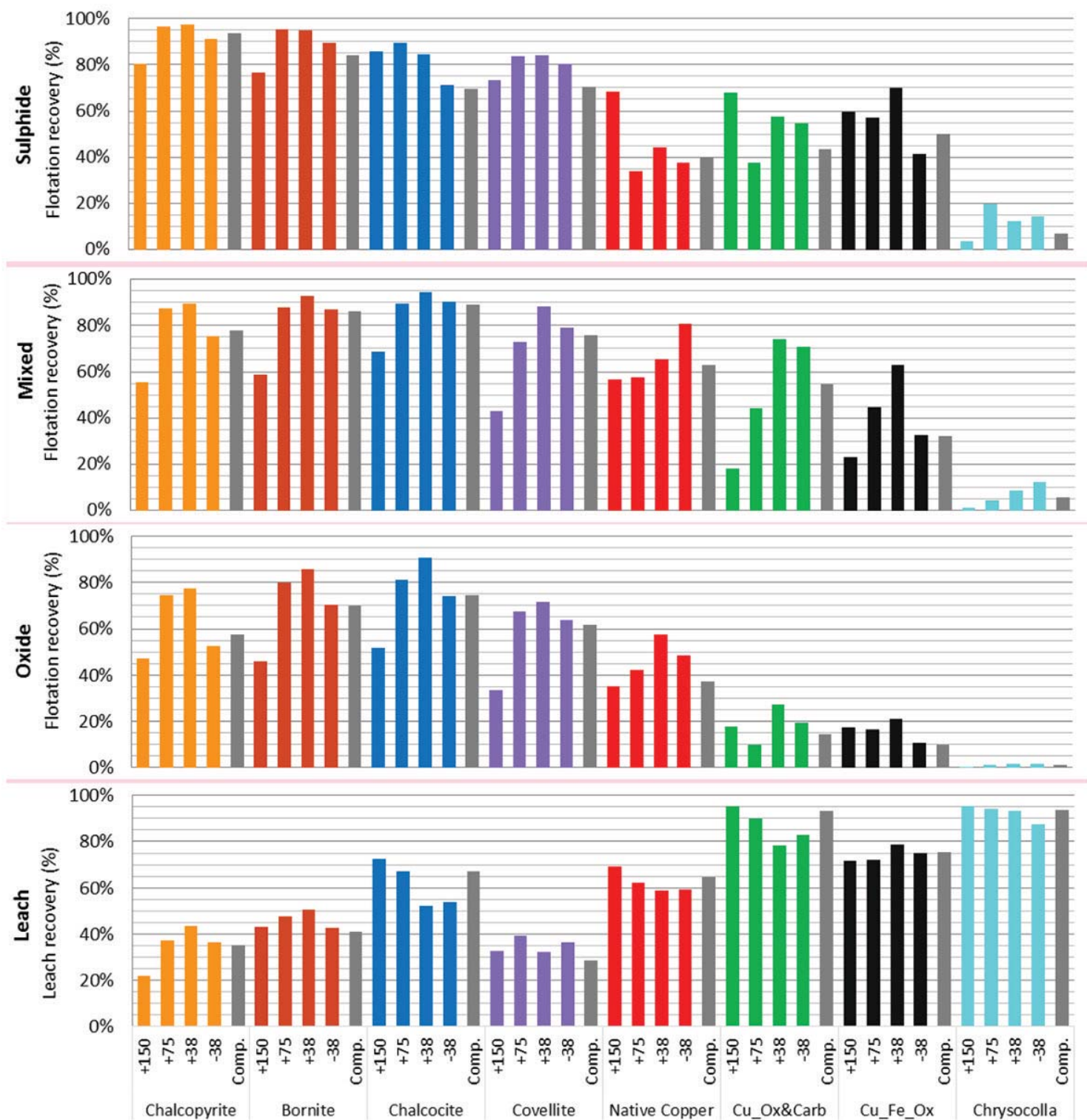

Figure 4-Recovery of copper minerals by size for each circuit. Comp. = composite

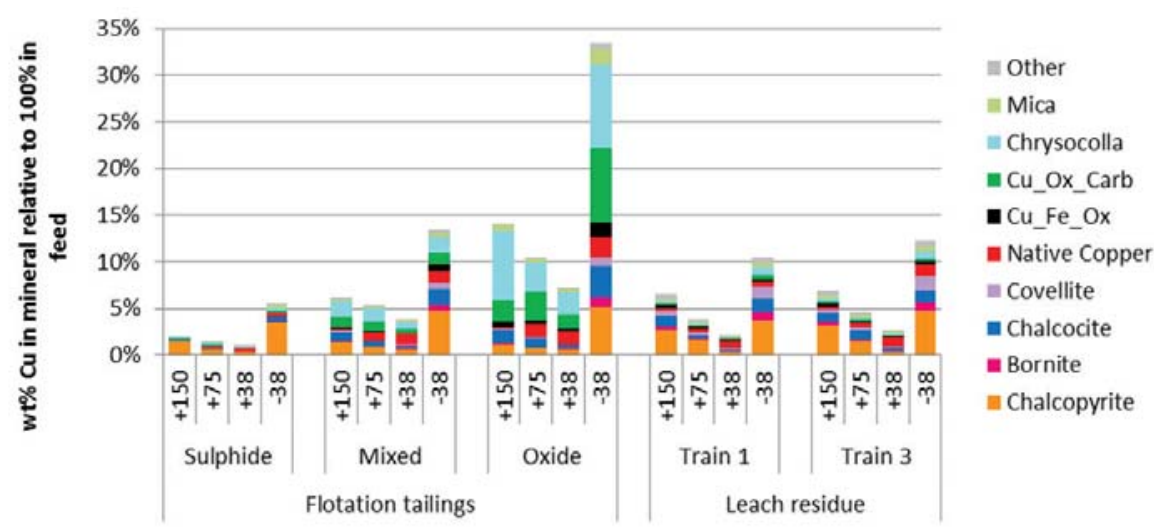

Figure 5-Normalized copper losses by mineral and by size as a percentage of the total copper fed to each circuit 


\section{Relationship between ore mineralogy and copper recovery across different processing circuits}

\section{Copper deportment}

The distribution of copper between different mineral hosts was originally identified as one of the key mineralogical variables to track at Kansanshi, and this has been the most useful mineralogical measurement for explaining variation in grade and recovery over time. Figure 3 shows how the copper in the feed to each circuit is recovered to the flotation concentrate or lost to the flotation tails, depending on the copper deportment to different minerals. Figure 3 also describes the leaching of copper from various minerals in the two leach trains through comparison of the copper distribution in the leach feed to that in the solid residues discharged from the two leach trains. It is predominantly the copper sulphide minerals that are recovered to the concentrates, and chrysocolla and copper oxides and carbonates that are leached.

of the three flotation circuits, the sulphide circuit has the highest recovery $(>90 \%)$ due to the simple copper mineralization, with approximately $90 \%$ of the copper occurring in chalcopyrite. In the mixed ore, chalcopyrite hosts approximately $35 \%$ of the copper in the feed, and in the oxide ore this proportion is normally less than $20 \%$. In the oxide circuit, the flotation recovery is less than $50 \%$, as approximately $50 \%$ of the copper is contained in chrysocolla, cuprite, and malachite, which report to the oxide tails.

Fortunately, these minerals leach well, so it is the loss of chalcopyrite that is most detrimental to the combined float and leach recoveries in the oxide and mixed circuits. In the mixed circuit, controlled potential sulphidization (CPS) with addition of sodium hydrogen sulphide (NaHS) is used to improve flotation recovery of the secondary copper sulphide, copper oxide, and copper carbonate minerals. NaHS is also added to the oxide circuit and occasionally to the sulphide circuit for a similar purpose, but dosages are not currently controlled by CPS. Projects supported by mineralogy are under way to optimize NaHS dosages using CPS for both the oxide and the sulphide circuit.

Historically, little or none of the mixed float tails was sent to the leach circuit, so more effort was made to recover the copper oxide and carbonate minerals by flotation in the mixed circuit, with multiple CPS stages and regular trials of new reagents designed to improve recovery of these minerals (Pacquot and Ngulube, 2015; Corin et al., 2017). Recently, due to the abundance of acid available from the smelter and quantitative mineralogy describing the losses in the mixed flotation tails, the leach circuit has been reconfigured to increase capacity and allow for processing of up to $100 \%$ of the mixed flotation tails.

The mineralization that leads to difficulty in achieving high flotation recoveries in the mixed and oxide circuits has a positive effect on concentrate grade. For the sulphide circuit, to achieve a target grade of $24 \%$ total copper the concentrate has to contain $70 \%$ chalcopyrite by mass as chalcopyrite has a relatively low copper content (34.8\%). On the other hand, chalcocite has a copper content of approximately $80 \%$, so for the mixed and oxide concentrates it is possible to achieve grades of over $40 \%$. For this reason, the operating strategy for the sulphide circuit places greater emphasis on pyrite and non-sulphide gangue rejection than the other circuits, with a chalcopyrite-selective collector and Jameson cells used for cleaning the final concentrate (wash water reduces entrainment). The effects are evident in the bulk mineralogy of the concentrate (Figure 2), which shows more copper minerals and less pyrite in the sulphide concentrate than in the mixed and oxide concentrates, while the copper grades of the three concentrates are $22 \%, 28 \%$, and $30 \%$, respectively (average for the year to date).

\section{Copper mineral recoveries}

The ability to calculate recoveries of individual copper minerals within a circuit provides a valuable tool for assessing operating factors influencing both flotation and leach performance, as well as for understanding how ore variability affects performance. The recoveries and leach efficiencies of the major copper-hosting minerals are presented in Table I, and the copper mineral recoveries by size fraction are presented in Figure 4. It is apparent that it is not only the distribution of copper to different minerals in the three circuits that influences recovery, but the recovery of each mineral also varies across the different circuits. The recovery of chalcopyrite is highest in the sulphide circuit (94\%), moderate in the mixed circuit (78\%), and poor in the oxide circuit (57\%). This variation is likely a result of differences in the surface chemistry of the chalcopyrite grains, which may be influenced by multiple variables. Key factors identified that could influence the chalcopyrite grain surfaces include the stream's bulk mineralogy (affecting iron and copper species in solution), the grinding environment (different quality steel media used), and the pulp potential (modified by addition of NaHS) (Heyes and Trahar, 1979; Bruckard, Sparrow, and Woodcock, 2011; Chen, Peng, and Bradshaw, 2014; Greet et al., 2004; Whiteman. Lotter, and Amos, 2016; Lotter, Bradshaw, and Barnes, 2016).
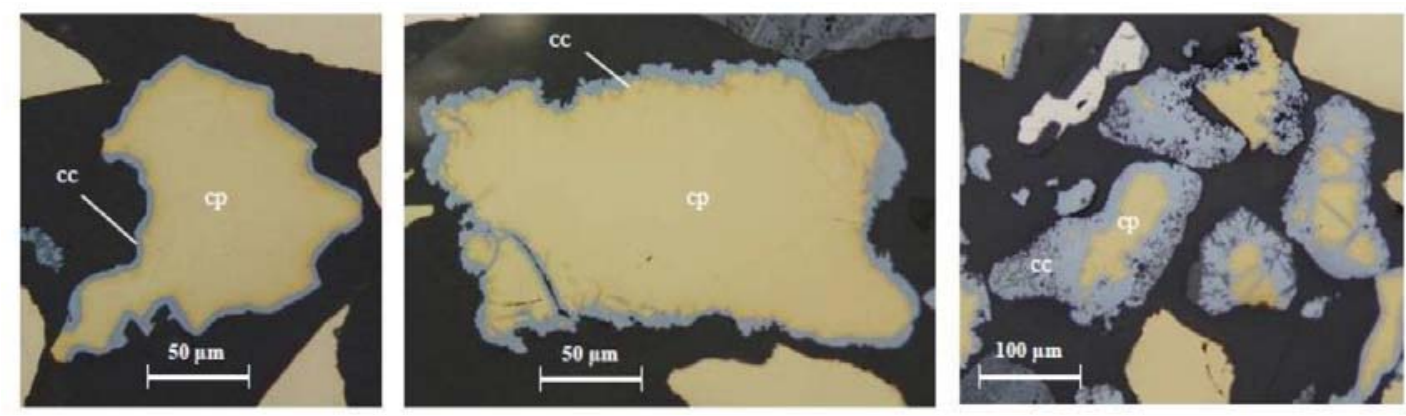

Figure 6-Reflected light photomicrographs of chalcocite (cc) rimming chalcopyrite (cp) particles in the mixed ore (Kottgen and Bastin, 2009) 

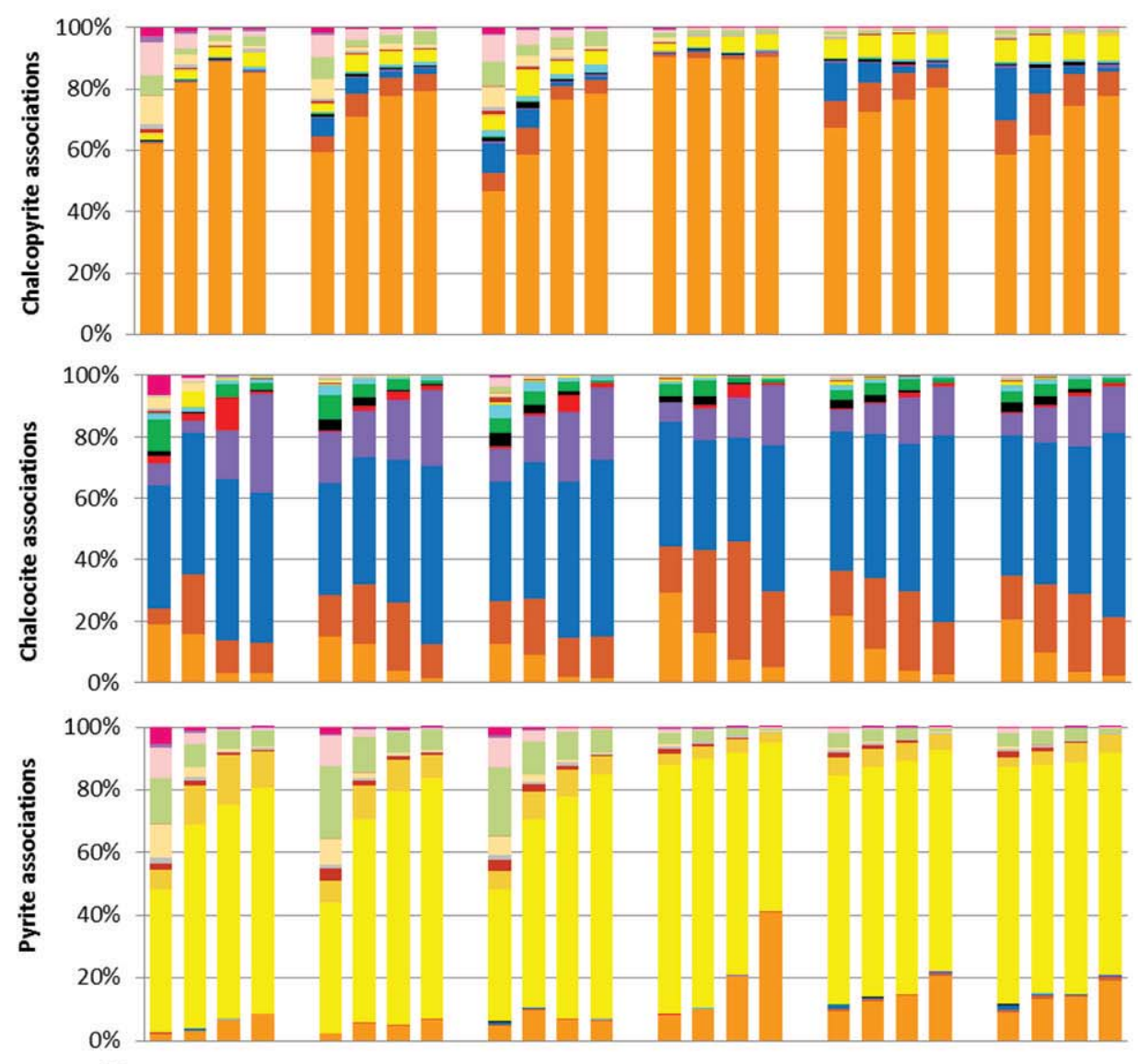

Calcite

- Dolomite

nuartz

mica

Elay

Feldspar

플

- Fe oxides

- Pyrrhotite

Pyrite

n Chrysocolla

- Cu_Ox \& Carb

- CuFe Oxides

- Native Copper

- Covellite

- Chalcocite

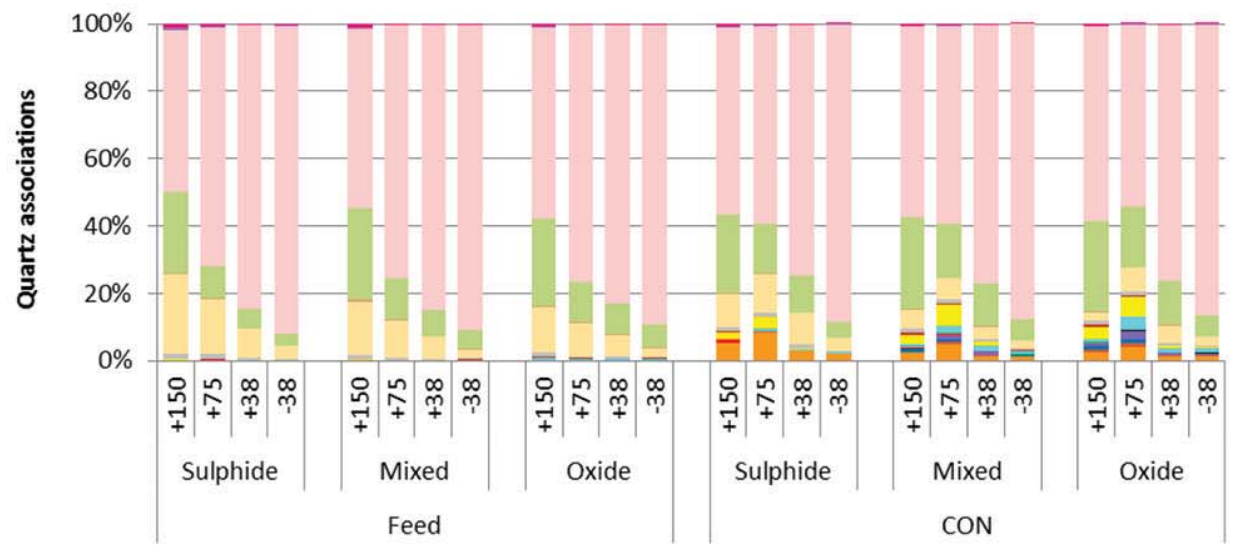

nornite

- Chalcopyrite

Figure 7-Associations of chalcopyrite, chalcocite, pyrite, and quartz with other minerals in the feed and flotation concentrate of each circuit. The colour for the selected mineral is used to show the association of that mineral with 'background', which is an indication of extent of liberation

Of the secondary copper sulphides, bornite has the highest recoveries in the sulphide circuit with similar behaviour to chalcopyrite, whereas chalcocite has the highest recoveries in the mixed and oxide circuits. This is consistent with observations in the literature that the Eh ranges for optimal flotation of chalcopyrite and chalcocite differ due to the difference in semiconductor types, with chalcocite floating better at more negative Eh (Lotter, Bradshaw, and Barnes, 2016). Additional CPS stages are likely responsible for higher recoveries of chalcocite, native copper, and copper oxides and carbonates in the mixed circuit (Pacquot and Ngulube, 2015), and this reasoning has motivated CPS projects for the oxide and sulphide circuit to further improve flotation recoveries. Variation in the different $\mathrm{Cu}$ mineral head grades across the three circuits could also account for some of the variation in mineral recoveries, with the sulphide ore having the highest chalcopyrite head grade and very low head grades for the other copper minerals. The year-to-date chalcocite head grades for the sulphide, mixed, and oxide circuits are $0.01 \%$, $0.28 \%$, and $0.33 \%$, which perhaps accounts for the difference in chalcocite recovery between sulphide and mixed, but not between mixed and oxide. 


\section{Relationship between ore mineralogy and copper recovery across different processing circuits}

The effects of particle size on flotation performance have been well documented (Feng and Aldrich, 1999), and the traditional 'optimal particle size range for flotation' with a $P_{80}$ of $150 \mu \mathrm{m}$ has been targeted since the plant was commissioned. The size-by-size recovery data (Figure 4) seems to justify this approach, with flotation recoveries of the sulphide minerals higher for the $-150+75 \mu \mathrm{m}$ and $-75+38 \mu \mathrm{m}$ fractions than for the $+150 \mu \mathrm{m}$ and $-38 \mu \mathrm{m}$ fractions. However, in Figure 5 it is evident that losses in the $-38 \mu \mathrm{m}$ fraction are typically greater than those in the other size fractions, indicating that perhaps a coarser and steeper particle size distribution would be preferable.

Many projects have been implemented to reduce the fines losses. In the sulphide circuit, Jameson cells (Glencore Technology, 2017) were installed in August 2017, and ProFlote (paramagnetism to agglomerate fines) is currently being trialled (FLSmidth, 2018). To reduce fines generation in the mixed circuit, the discharge mechanism of the ball mill was converted from grate to overflow in mid-2017, which led to a substantial increase in recovery. High-shear stators have also been trialled for improving fines recovery.

\section{Mineral associations}

Apart from mineral abundance and copper distribution, understanding the liberation and associations of key minerals is important for explaining mineral behaviour in processing and identifying opportunities for improvements (Evans and Morrison, 2016; Fandrich et al., 2007; Albijanic et al., 2014; Whiteman, Lotter, and Amos, 2016). A commonly occurring association texture, that of rimming of chalcopyrite with chalcocite, is shown in Figure 6 (PérezBarnuevo, Pirard, and Castroviejo, 2013; Jacobs, 2016). The associations of chalcopyrite, chalcocite, pyrite, and quartz with other minerals in the feed and flotation concentrate streams of each circuit are quantified in Figure 7. In each graph, the colour of the selected mineral is used to indicate the associations of that mineral with 'background', which is an indication of the extent of liberation. By this measure, of the four minerals, chalcopyrite and quartz have the greatest extent of liberation. As expected, in all of the feed streams liberation increases with decreasing particle size.

Figure 7 shows that chalcopyrite and pyrite have significant associations with quartz, mica, and feldspar in the coarse fractions of the feeds, and it is clear that these associations have a negative impact on recovery as the concentrates indicate much lower associations with these non-sulphide gangue minerals. Chalcocite has negligible associations with gangue minerals and is almost entirely associated with other copper minerals, predominantly covellite, bornite, and chalcopyrite. In the sulphide circuit, chalcocite associated with bornite and chalcopyrite is more likely to be recovered than liberated chalcocite, while liberated chalcocite appears to have the highest recoveries in the mixed and oxide circuits. Associations of chalcocite with covellite, chrysocolla, cuprite, and malachite ( $\mathrm{Cu}$ ox \& carb) seem to adversely affect chalcocite recovery.

A large proportion of pyrite recovered to the concentrates is liberated, and the remainder is associated with pyrrhotite, chalcopyrite, or mica. Similarly, a large proportion of the quartz recovered is either liberated or associated with other non-sulphide gangue minerals, which implies recovery by entrainment. Nevertheless, association of quartz with copper minerals and pyrite does account for a significant proportion of the quartz recovered in the coarse size fractions.

Across the three circuits, the main differences observed are in the association of chalcopyrite and quartz with secondary copper sulphides, which is due to weathering and supergene enrichment. It was noted in the previous section that chalcopyrite has lower recoveries in the oxide and mixed circuits than in the sulphide circuit. Figure 7 suggests that in the oxide and mixed circuits, chalcopyrite is slightly poorer liberated and is more often associated with other minerals than in the sulphide circuit, which likely contributes to the lower chalcopyrite recovery, but does not fully explain the difference observed.

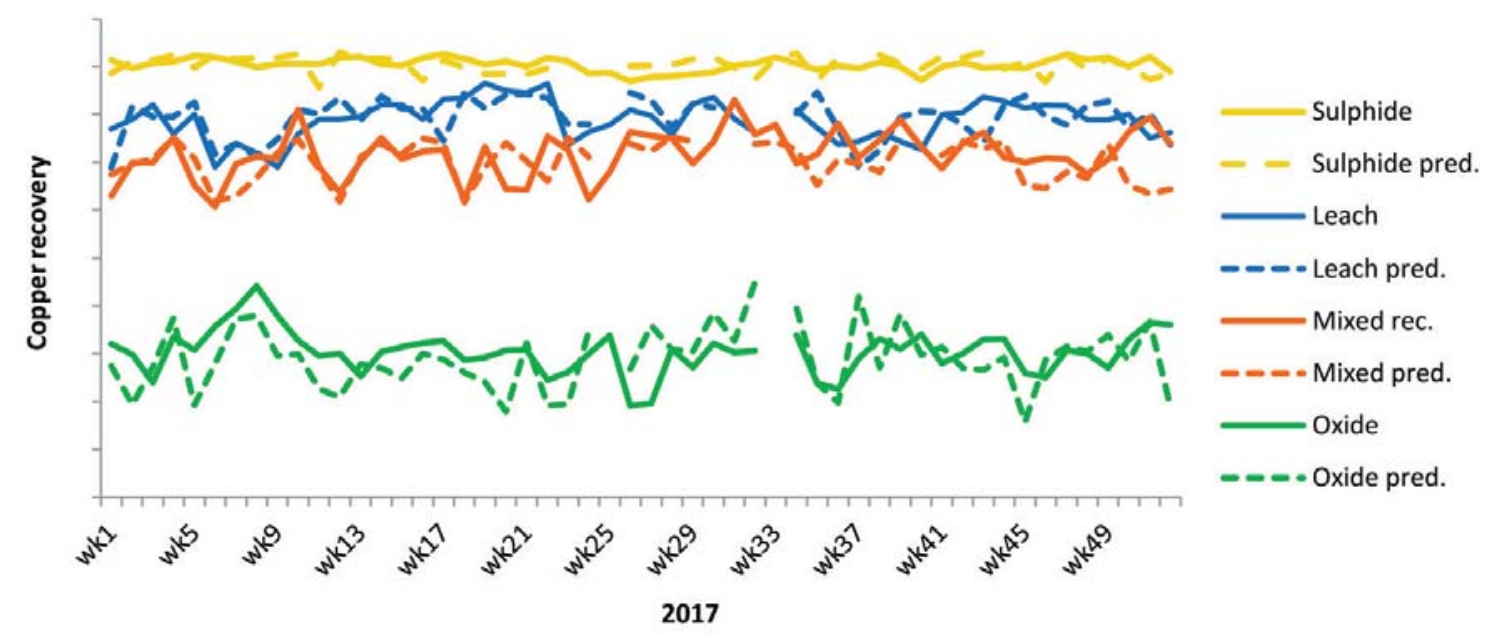

Figure 8-Total copper recovery vs. mineralogy-predicted recovery for each circuit in 2017 


\section{Relationship between ore mineralogy and copper recovery across different processing circuits}

\section{Use of mineralogy to assess plant performance}

The average recoveries of each copper mineral for the year 2016 were used to calculate predicted recoveries for each circuit based on variation in feed copper deportment for 2017. These mineralogy-predicted recoveries are compared to measured recoveries in Figure 8, which shows actual recovery versus mineralogy-predicted recovery for the four circuits in 2017. This graph (going forward) provides a useful tool to identify periods of high and low recovery that can be explained by variations in feed mineralogy, thus improving interpretation of the impacts of operational and circuit changes. Figure 8 also illustrates that the variability of feed mineralogy is much greater for the mixed and oxide ores than it is for the hypogene sulphide ore, and this in turn leads to high variability in flotation recovery as compared to the sulphide circuit.

\section{Conclusions}

The relative abundance of copper minerals in the ores fed to each of the processing circuits at Kansanshi has a strong impact on process performance. The fresh, hypogene sulphide ore, with approximately $90 \%$ of the contained copper hosted in chalcopyrite, has consistently high flotation recoveries with minimal variation in flotation performance. In the oxide and mixed circuits, the copper mineralogy is much more variable depending on the extent of oxidation and supergene enrichment, which causes large fluctuations in both copper recovery and flotation concentrate grade.

Quantitative mineralogy using automated SEM provides an understanding of the relationship between process performance and mineralogy. At Kansanshi, it has delivered significant value by highlighting opportunities for grade and recovery improvement projects, which have included reagent suite optimization and circuit modifications. Key circuit modifications guided by process mineralogy have included the change of the mixed circuit ball mill discharge mechanism, the installation of Jameson cells, and CPS for the sulphide circuit (still in progress).

\section{Acknowledgements}

The authors would like to thank First Quantum Minerals and Kansanshi Mining plc management for funding and supporting mineralogical studies at Kansanshi, and for allowing the publication of this work. Edward Paul, Monica Kalichini, and Busiku Hamilemba have all been responsible for developing and maintaining the programme over certain periods, and the mineralogy sample-preparation team plays an essential role in consistently producing high-quality samples for analysis. We appreciate the contributions of Will Goodall, James Strongman, and colleagues from MinAssist and iMinSolutions for technical support since the inception of the Kansanshi mineralogy programme. The Carl Zeiss service team has also worked hard to help us keep the MinSCAN and ancilliary equipment running full-time.

\section{References}

Albijanic, B., Subasinghe, N., Bradshaw, D.J., and Nguyen, A.V. 2014. Influence of liberation on bubble-particle attachment time in flotation. Minerals Engineering, vol. 74. pp. 156-162.
BRuCKard, W.J., Sparrow, G.J., and WoOdCock, J.T. 2011. A review of the effects of the grinding environment on the flotation of copper sulphides. International Journal of Mineral Processing, vol. 100, no. 1-2. pp. 1-13.

Chen, X., Peng, Y., and Bradshaw, D. 2014. The effect of particle breakage mechanisms during regrinding on the subsequent cleaner flotation. Minerals Engineering, vol. 66-68. pp. 157-164.

Corin, K.C., Kalichini, M., Connor, C.T.O., and Simukanga, S. 2017. The recovery of oxide copper minerals from a complex copper ore by sulphidisation. Minerals Engineering, vol. 102. pp. 15-17.

Evans, C.L. and MoRrison, R.D. 2016. Mineral liberation. Process Mineralogy, Becker, M., Wightman, E.M., and Evans, C. (eds). Julius Kruttschnitt Mineral Research Centre, Indooroopilly, Queensland, Australia.

FAndrich, R., BEARMAn, R.G., Boland, J., and Lim, W. 2007. Modern SEM-based mineral liberation analysis. International Journal of Mineral Processing, vol. 84, no. 1-4. pp. 310-320.

FENG, D. and AlDRICH, C. 1999. Effect of particle size on flotation performance of complex sulphide ores. Minerals Engineering, vol. 12, no. 7. pp. 721-731.

FLSmidTH. 2018. ProFlote flotation. http://www.flsmidth.com/enUS/Industries/Categories/

Products/Flotation/ProFloteFlotation/ProFloteFlotation [accessed 16 March 2018].

Glencore Technology. 2017. Jameson cell. http://www.jamesoncell.com/en/Pages/home.aspx

Greet, C., Small, G.L., Steinier, P., and Grano, S.R. 2004. The Magotteaux mill: investigating the effect of grinding media on pulp chemistry and flotation performance. Minerals Engineering, vol. 17, no. 7-8. pp. 891-896.

Heyes, G.W. and Trahar, W.J. 1979. Oxidation-reduction effects in the flotation of chalcocite and cuprite. International Journal of Mineral Processing, vol. 6. pp. 229-252.

HiLL, E. 2014. Zeiss mineralogic mining - ore process optimization. White Paper. Carl Zeiss, Jena, Germany.

JAcoBs, T.T. 2016. Process mineralogical characterisation of the Kansanshi copper ore, NW Zambia. MSc thesis, Department of Chemical Engineering, University of Cape Town. https://open.uct.ac.za/handle/11427/20490

KALICHINI, M.S. 2015. A study of the flotation characteristics of a complex copper ore. MSc thesis, Department of Chemical Engineering, University of Cape Town. http://hdl.handle.net/11427/16196

Kalichini, M.S., Goodall, W.R., Paul, E.M., Prinsloo, A., and Chongo, C. 2017. Applied mineralogy at Kansanshi mine - proof of the concept of on-site routine process mineralogy for continuous improvement of plant operations. Proceedings of Process Mineralogy '17, Cape Town. Minerals Engineering International, Falmouth, UK. pp. 1-10.

KotTGEN, A. and BAStin, D. 2009. Mineralogical analysis of the "Red Ore" flotation circuit - Kansanshi. University of Liège. https://orbi.uliege.be/handle/2268/155492

LotTer, N.O., Bradshaw, D.J., and Barnes, A.R. 2016. Classification of the major copper sulphides into semiconductor types, and associated flotation characteristics. Minerals Engineering, vol. 96-97. pp. 177-184.

Pacquot, F. and Ngulube, C. 2015. Development and optimization of mixed sulphide/ oxide copper ore treatment at Kansanshi. Journal of the Southeren African Institute of Mining and Metallurgy, vol. 115. pp. 1253-1258.

Pérez-Barnuevo, L., Pirard, E., and Castroviejo, R. 2013. Automated characterisation of intergrowth textures in mineral particles. A case study. Minerals Engineering, vol. 52. pp. 136-142.

Whiteman, E., LotTer, N.O., and Amos, S.R. 2016. Process mineralogy as a predictive tool for flowsheet design to advance the Kamoa project. Minerals Engineering, vol. 96-97. pp. 185-193. 